Article

\title{
Comparative Morphology and Biochemical Analysis of Nickel Toxicity in Minor Fruit Species (Grewia asiatica L., Syzgium cumini (L.) Skeels and Tamarindus indica L.)
}

\author{
Saman Zahra ${ }^{1}$, Sibgha Noreen ${ }^{1}$, Rafia Abid ${ }^{1}$, Ahmed Akram ${ }^{1}$, Seema Mahmood ${ }^{1, *}$, Tariq Shah ${ }^{2}$ \\ and Abdulaziz Abdulla Alsahli ${ }^{3}$ (D)
}

check for updates

Citation: Zahra, S.; Noreen, S.; Abid, R.; Akram, A.; Mahmood, S.; Shah, T.; Alsahli, A.A. Comparative

Morphology and Biochemical Analysis of Nickel Toxicity in Minor Fruit Species (Grewia asiatica L., Syzgium cumini (L.) Skeels and Tamarindus indica L.). Agriculture 2022, 12, 323. https://doi.org/10.3390/ agriculture12030323

Academic Editors: Mohsin Tanveer, Muhammad Suleman Tahir, Zerihun Tadele and Adnan Noor Shah

Received: 5 October 2021

Accepted: 27 December 2021

Published: 23 February 2022

Publisher's Note: MDPI stays neutral with regard to jurisdictional claims in published maps and institutional affiliations.

Copyright: (C) 2022 by the authors. Licensee MDPI, Basel, Switzerland. This article is an open access article distributed under the terms and conditions of the Creative Commons Attribution (CC BY) license (https:// creativecommons.org/licenses/by/ $4.0 /)$.
1 Institute of Pure and Applied Biology, Bahauddin Zakariya University, Multan 60800, Pakistan; samanzahra_86@yahoo.uk (S.Z.); sibgha.noreen@bzu.edu.pk (S.N.); profrafia@gmail.com (R.A.); ahmedakrem@bzu.edu.pk (A.A.)

2 Department of Agroecology, University of Bourgogne, 21000 Dijon, France; tariq.shah@inrae.fr

3 Botany and Microbiology Department, College of Science, King Saud University, P.O. Box 2460, Riyadh 11451, Saudi Arabia; aalshenaifi@ksu.edu.sa

* Correspondence: seemamehmood@bzu.edu.pk

\begin{abstract}
We evaluated the growth potential of three minor fruit species (Grewia asiatica L., Syzgium cummini and Tamarindus indica L.) after exposure to increasing Ni levels (0, 10, 20 and $40 \mu \mathrm{g} \mathrm{kg}^{-1}$ soil). The growth attributes, lipid peroxidation, photosynthetic machinery, macro nutrients and capacity of enzymatic antioxidants; Superoxide dismutase (SOD), Catalase (CAT) and Peroxidase (POD) in both leaves and roots were investigated under Ni exposure. A significant reduction in the biomass elongation of tissues (root and shoot) and enhanced oxidative damage via malondialdehyde (MDA) were noticed in all three species. Ni exposure triggered an induction of antioxidant enzyme response in a concurrent manner. Simultaneous increases in the antioxidant activities in the roots of G. asiatica and in the leaves of S. cumini suggest the existence of a sequence response against tissue damage. However, the activities of antioxidant enzymes in the tissues of $T$. indica were insufficient to counteract the elevated MDA levels. G. asiatica exhibited its resilience through the restricted transfer of $\mathrm{Ni}$ to aerial tissue, adequate uptake of nutrients, robust chloroplasts with lesser biodegradation of chlorophyll molecules and enhanced capacity of antioxidant enzyme biosynthesis. Thus, lesser modulations of morpho-biochemical expressions and the activity of antioxidants seem to contribute important defense mechanisms against Ni stress in the species.
\end{abstract}

Keywords: antioxidant enzymes; minor fruit species; malondialdehyde (MDA); nickel; reactive oxygen species (ROS)

\section{Introduction}

An extensive range of both essential (copper, nickel, manganese, molybdenum, iron and zinc) and non-essential (cadmium, chromium, cobalt, lead and mercury) metals are released into ecosystem from various sources [1]. During the industrial revolution era, nickel (Ni) concentrations in the environment substantially increased [2] through various sources, including municipal waste, vehicular emissions, fertilizers, batteries, electroplating and food industries. As a result of these, agricultural soils act as an ultimate sink of Ni, which is then taken up by plants and transferred into the food chain [3].

Edible fruit species possess characteristic aromas and tastes and are grown in many parts of the world for dietary requirements/health benefits. Two broad categories (major and minor) of fruit species are recognized based on the magnitude of their production and consumption [4]. Minor fruit species hold good commercial value, with several medicinal and therapeutic uses, and can be consumed in raw/fresh or processed forms. Substantial revenue can be generated through the marketing and export of these fruits and their 
products, resulting in a positive impact on society through socioeconomic development. However, minor fruits are only produced on a small scale despite their vast potential for growth in different geographical areas with a wide array of soil and climatic conditions. Furthermore, the rapid expansion of cities and urbanization in the developing world has resulted in the reduced production of fruits, as reported by World Economic and Social Survey, Sustainable Development Challenges [5]. In addition, the industrial revolution has resulted in the contamination of the environment, which has drastically affected biodiversity and the ecosystem, with hazardous consequences for all life forms [6].

$\mathrm{Ni}$ is an essential growth component required in an optimum range, but it is more detrimental at supra-optimal levels than deficient concentrations [7]. The effects of exceeding Ni levels have been widely reported for a number of plant species, with specific descriptions of the detrimental impact of elevated Ni levels, such as inhibition of cell division, biomass production and growth components [8]. Similarly, the degradation of chlorophyll [9], inhibition of photosynthesis [10], water imbalance [11], and alterations in the transport of macro $\left(\mathrm{Na}^{+}, \mathrm{K}^{+}, \mathrm{Ca}^{2+}\right.$ and $\left.\mathrm{Mg}^{2+}\right)$ and micro nutrients $\left(\mathrm{Fe}^{2+}, \mathrm{Mn}^{2+}, \mathrm{Cu}^{2+}\right.$ and $\mathrm{Zn}^{2+}$ ), owing to the substitution of $\mathrm{Ni}$ with essential mineral nutrients [12], inhibition of enzyme functions and metabolism [13], are also well documented.

An excess of $\mathrm{Ni}$ induces the synthesis of certain byproducts of various metabolic cycles, collectively called reactive oxygen species (ROS), in different cellular compartments [14] ROS can cause oxidative damage in the absence of sufficient scavenging capacity or cellular defense [15]. The destruction of biological membranes through the peroxidation of lipids is the most devastating effect of ROS production [16].

The mitigation of ROS is accomplished through the biosynthesis of either non-enzymatic or enzymatic antioxidants and sometimes both [17]. However, the type of metal and its concentration are the main determinants that either trigger or inhibit the biosynthesis of these antioxidants $[18,19]$. The detoxification of ROS through non-enzymatic components has been well reported [20], but enzymatic ROS scavengers have received more attention because of their active defensive role. A significant number of studies have clearly demonstrated the implications of superoxide dismutase (SOD), catalase (CAT) and peroxidases (POD) in the alleviation of various environmental stresses in plants [21-23]. These enzymes exist in cytosol and within compartments of cellular organelles (chloroplast, mitochondria and peroxisomes), acting as potential ROS scavengers in plants [24].

An ample number of investigations have been carried out for several crop plants and tree species, but limited information is available on the effects of various levels of $\mathrm{Ni}$ on the morpho-biochemical responses of minor fruits (Grewia asiatica, Syzgium cumini and Tamarindus indica). Therefore, we investigated these species in our study. Additionally, tree species were selected because they have better threshold for metal stress than many non-woody/ herbaceous plants [25]. Therefore, three tree species were selected for the study and aimed to reveal alterations of morphological and biochemical attributes, as well as changes in nutrient uptake, oxidative damage (via lipid peroxidation) and defensive responses represented by enzymatic antioxidants (SOD, CAT and POD) in leaves and roots to suggest differential performances of species under various $\mathrm{Ni}$ levels. The results of the study will help us understand the adaptive strategies of these species for growth in $\mathrm{Ni}$ contaminated soil and suggest future perspectives for green technology for environmental cleanup (phytoremediation) by using economically important species for the maximum utilization of soil resources.

\section{Materials and Methods}

\subsection{Plant Growth and Nickel Treatments}

One hundred seeds of Grewia asiatica L., Syzgium cumini (L.) skeels were separated from their fresh fruits, while the pulp of Tamarindus indica L. was used as the seed source. Seedling establishment and growth experiments were conducted using sandy loam soil ( $\mathrm{pH}$ of 7.90 , containing 50,30 and $20 \%$ of sand, clay and silt, respectively) with field capacity, wilting point and available water values of $1.4,0.6$ and $0.8 \mathrm{~mm} / \mathrm{cm}$ depth of soil, 
correspondingly. The seedlings were raised by sowing seeds of each species separately using plastic pots (height, $15 \mathrm{~cm}$; diameter, $8 \mathrm{~cm}$ ) filled with sandy loam soil. After 4 weeks, five vigorously growing plants $(6-8 \mathrm{~cm})$ of each species bearing $2-4$ leaves were further potted into plastic pots with the following dimensions: height, $42 \mathrm{~cm}$; diameter, $30 \mathrm{~cm}$. There were 12 pots, $4 \mathrm{Ni}$ levels and 3 replications for each of the 3 species. These pots were filled with $6 \mathrm{~kg}$ of air-dried garden soil (sandy loam) sieved through $2 \mathrm{~mm}$ mesh size. $\mathrm{NiCl}_{2} \cdot 6 \mathrm{H}_{2} \mathrm{O}$ (Merck, Darmstadt, Germany) was thoroughly mixed with the soil substrate individually at the beginning of the experiment at 10,20 and $40 \mu \mathrm{g} \mathrm{kg}^{-1}$, while control plants were without $\mathrm{Ni}$. Ni (4.05 g) was used as actual concentration of metal in the source $\left(\mathrm{NiCl}_{2} \cdot 6 \mathrm{H}_{2} \mathrm{O}\right)$. The concentrations used were carefully chosen after a preliminary experiment and were based on Ni levels detected in agricultural soils of urban areas of Multan, Pakistan.

The growth experiment was systematically placed in a complete randomized design and continued for 8 weeks.

\subsection{Growth Components}

The elongation of the two tissues (root and shoot), along with their fresh and dry biomass, was measured. The number of leaves on each plant was counted and area measurements were taken using a benchtop area meter LI 3100C (LI-COR Bioscience, Lincoln, Nebraska, USA). Dry-weight measurements were conducted after oven drying the plant material at $80{ }^{\circ} \mathrm{C}$ for $48 \mathrm{~h}$. Randomly chosen subsets of roots and leaves were instantly frozen to perform enzymatic analyses. The roots were immersed in $1 \% \mathrm{Li} \mathrm{NO}_{3}$ solution to avoid the leaching of metal ions from the roots.

\subsection{Photosynthetic Pigments}

The Arnon [26] technique was used for the estimation of chlorophyll. An amount of $1.0 \mathrm{~g}$ of leaves was extracted in $80 \%$ acetone. The material was then centrifuged at $4{ }^{\circ} \mathrm{C}$ for $20 \mathrm{~min}$ at $13,000 \times \mathrm{g}$. The optical densities of the supernatant were spectrophotometrically read at 645 and $663 \mathrm{~nm}$ (UV-1900i, Shimadzu Cooperation, Kyoto, Japan).

\subsection{Determination of Macronutrients and Nickel}

$\mathrm{Na}^{+}, \mathrm{K}^{+}, \mathrm{Ca}^{2+}, \mathrm{Mg}^{2+}$ and $\mathrm{Ni}$ contents in plant tissues (leaves and roots) were estimated, followed by the wet digestion of dried samples using double acid $\left(\mathrm{HNO}_{3}: \mathrm{HClO}_{4}\right)$ in a 3:1 $(v / v)$ ratio [26]. The Microwave Digestion System (MDS 2000, Ottawa, Canada) set at $100{ }^{\circ} \mathrm{C}$ was used to obtain digested mixture. The amounts of $\mathrm{Na}^{+}, \mathrm{K}^{+}$and $\mathrm{Ca}^{2+}$ were determined with a flame photometer (Jenway, PFP-7, Stafford, UK) using a standard curve. However, $\mathrm{Mg}^{2+}$ was determined by AAS (Atomic Absorption Spectrophotometer, Varian, 1475, Palo Alto, CA, USA). AA Standards (Camlab, Cambridge, UK) were used for the accurate determination of $\mathrm{Ni}$ content, at $0.01 \mu \mathrm{g} / \mathrm{L}$, with a $96-98 \%$ recovery rate and variability index of $3.5-10 \%$.

\subsection{MDA in Tissues}

Thiobarbituric-acid-reactive substances representing the final decomposition and the lipid peroxidation product (MDA) were used as stress indicators. In total, $5 \mathrm{~mL}$ of a solution of 20\% trichloroacetic acid and 0.5\% 2-thiobarbituric acid was used for the homogenization of $1.0 \mathrm{~g}$ leaves and roots. Heating of the mixture at $95{ }^{\circ} \mathrm{C}$ for $30 \mathrm{~min}$ was carried out, followed by quick cooling in an ice bath and then centrifugation at $5000 \times g$ for $10 \mathrm{~min}$ at $25^{\circ} \mathrm{C}$. The absorbance of the supernatant was recorded at 532 and $600 \mathrm{~nm}$. After subtracting the nonspecific turbidity at $600 \mathrm{~nm}$, the MDA concentration was determined by its molar extinction coefficient, $155 \mathrm{mmol} / \mathrm{L} \mathrm{cm}$, according to Kosugi and Kikugawa [27].

\subsection{Activity of Antioxidant Enzymes}

Antioxidant enzymes were determined from the leaves and roots $(0.5 \mathrm{~g})$ from finely ground material by using $50 \mathrm{mM}$ cooled phosphate buffer ( $\mathrm{pH} 7.8$ ). The filtration of 
homogenate through a cheesecloth was carried out by centrifugation at $15,000 \times g$ for $20 \mathrm{~min}$ at $4{ }^{\circ} \mathrm{C}$. The supernatant was used for an assay to determine the activity of antioxidant enzymes. The absorbance wavelengths were 240,470 and $560 \mathrm{~nm}$ for CAT, SOD and POD, respectively. The activity of each enzyme is expressed in units per min and $\mathrm{mg}$ of protein. The method reported by Beauchamp and Fridovich [28] was followed to determine the activity of SOD by photoreduction of nitroblue tetrazolium (NBT). The production of blue formazan as a result of the photoreduction of NBT was used to read the absorbance at $560 \mathrm{~nm}$. One unit of SOD is regarded as the activity of an enzyme that can inhibit the photoreduction of NBT to blue formazan by $50 \%$. Catalase (CAT) activity was assayed [29] by decomposition of $\mathrm{H}_{2} \mathrm{O}_{2}$ and the change in absorbance due to $\mathrm{H}_{2} \mathrm{O}_{2}$ was spectrophotometrically observed every $30 \mathrm{~s}$ for $5 \mathrm{~min}$ at $240 \mathrm{~nm}$ using its molar extinction coefficient $(36 \mathrm{~mol} / 1 \mathrm{~cm})$. POD catalyzes the transformation of guaiacol to tetraguaiacol (brown product) in the presence of $\mathrm{H}_{2} \mathrm{O}_{2}$. Therefore, $\mathrm{POD}$ activity was determined with guaiacol oxidation at $25^{\circ} \mathrm{C}$ by a method described in [30].

\subsection{Statistical Analysis}

The data for each parameter are presented as means ( \pm S.E.). In order to determine significant differences among the main factors (species and Ni levels), a two-factor (twoway) analysis of variance (ANOVA) was carried out with replication using MS EXCEL, 2010 Version 14.0 (Microsoft ${ }^{\circledR}$ for Windows 7, Redmond, Washington, USA., 2010) Multiple comparisons between the mean values for the main factors were carried out by least significant differences (LSD), following the method described by Snedecor and Cochran [31]. The values for the correlation coefficient $(r)$ were calculated between variables (amount of Ni tissues and parameters), and the significance of each $r$ value was determined by a Student's $t$-test.

\section{Results}

\subsection{Modulation of Growth Components}

A gradual decline in shoot fresh weight was observed in species studied, but the reduction in shoot fresh biomass was more drastic in S. cumini, which had $0.92 \mathrm{~g}$ fresh biomass at the highest level of $\mathrm{Ni}$, compared to its corresponding control (4.03 g). An approximate three-fold decline in dry biomass of the shoot was observed in all species at the highest $\mathrm{Ni}$ concentration (Table 1). The decline in root fresh weight was not as intense in T. indica, despite the exposure of plants to the most elevated Ni levels. However, a considerable reduction in root biomass was noticed in G. asiatica $(0.68 \mathrm{~g})$ and S. cumini $(0.71 \mathrm{~g})$ in response to $40 \mu \mathrm{g} \mathrm{kg}^{-1}$ of Ni. Both species and Ni levels varied significantly $(p \leq 0.05)$ for the biomass of the tissues, but multiple comparisons revealed a marked $(p \leq 0.05)$ variation for T. indica.

As far as the elongation of the two tissues is concerned, shoot development was more influenced by Ni levels in G. asiatica, which exhibited a decline of almost $43 \%$ but more prolific root growth at all $\mathrm{Ni}$ levels except at $10 \mu \mathrm{g} \mathrm{kg}^{-1}$, where a decline of about $35 \%$ was noticed. The increment in root length was greater in S. cumini and T. indica despite exposure to $40 \mu \mathrm{g} \mathrm{kg}^{-1} \mathrm{Ni}$ in the rooting medium. Ni induced a marked reduction $(p \leq 0.05)$ in the elongation of the shoots. However, root elongation at all Ni levels did not vary markedly in all species. All growth parameters showed a decline with increasing concentrations of $\mathrm{Ni}$, but a significantly negative impact was noticed for dry biomass of the tissues in all species (Table 2). 
Table 1. Mean values ( \pm S.E.) of tissue (shoot and root) growth of three minor fruit species (Grewia asiatica L., Syzgium cumini (L.) Skeels and Tamarindus indica L.) following exposure to various levels of $\mathrm{Ni}$.

\begin{tabular}{|c|c|c|c|c|c|c|c|c|c|c|c|c|}
\hline \multirow{3}{*}{ Attributes } & \multicolumn{4}{|c|}{ G. asiatica L. } & \multicolumn{4}{|c|}{ S. cumini (L.) Skeels } & \multicolumn{4}{|c|}{ T. indica $\mathrm{L}$. } \\
\hline & \multicolumn{12}{|c|}{$\mathrm{Ni} \mu \mathrm{g} / \mathrm{kg}$} \\
\hline & Control & 10 & 20 & 40 & Control & 10 & 20 & 40 & Control & 10 & 20 & 40 \\
\hline $\begin{array}{c}\text { Shoot } \\
\text { fresh } \\
\text { weight }(\mathrm{g})\end{array}$ & $\begin{array}{l}3.14^{\mathrm{a}} \\
\pm 0.10\end{array}$ & $\begin{array}{l}2.65^{\mathrm{a}} \\
\pm 0.30\end{array}$ & $\begin{array}{l}1.86^{\mathrm{b}} \\
\pm 0.06\end{array}$ & $\begin{array}{l}0.95^{c} \\
\pm 0.14\end{array}$ & $\begin{array}{l}4.03^{\mathrm{a}} \\
\pm 0.89\end{array}$ & $\begin{array}{l}1.17^{\mathrm{c}} \\
\pm 0.21\end{array}$ & $\begin{array}{l}1.78^{c} \\
\pm 0.43\end{array}$ & $\begin{array}{l}0.92^{\mathrm{c}} \\
\pm 0.32\end{array}$ & $\begin{array}{l}2.81^{\mathrm{a}} \\
\pm 0.05\end{array}$ & $\begin{array}{l}2.12^{b} \\
\pm 0.09\end{array}$ & $\begin{array}{l}1.61^{\mathrm{c}} \\
\pm 0.07\end{array}$ & $\begin{array}{l}1.21^{\mathrm{d}} \\
\pm 0.04\end{array}$ \\
\hline $\begin{array}{l}\text { Shoot dry } \\
\text { weight (g) }\end{array}$ & $\begin{array}{l}1.12^{\mathrm{a}} \\
\pm 0.07\end{array}$ & $\begin{array}{l}0.98^{\mathrm{a}} \\
\pm 0.07\end{array}$ & $\begin{array}{l}0.49^{b} \\
\pm 0.05\end{array}$ & $\begin{array}{l}0.31^{\mathrm{b}} \\
\pm 0.02\end{array}$ & $\begin{array}{l}1.10^{\mathrm{ab}} \\
\pm 0.13\end{array}$ & $\begin{array}{l}0.76^{b c} \\
\pm 0.29\end{array}$ & $\begin{array}{l}0.94^{b c} \\
\pm 0.14\end{array}$ & $\begin{array}{l}0.29^{c} \\
\pm 0.05\end{array}$ & $\begin{array}{l}0.93^{\mathrm{a}} \\
\pm 0.04\end{array}$ & $\begin{array}{l}0.71^{\mathrm{b}} \\
\pm 0.03\end{array}$ & $\begin{array}{l}0.40^{\mathrm{c}} \\
\pm 0.01\end{array}$ & $\begin{array}{l}0.31^{\mathrm{d}} \\
\pm 0.02\end{array}$ \\
\hline $\begin{array}{l}\text { Root fresh } \\
\text { weight (g) }\end{array}$ & $\begin{array}{l}2.23^{\mathrm{a}} \\
\pm 0.14\end{array}$ & $\begin{array}{l}1.64^{\mathrm{b}} \\
\pm 0.12\end{array}$ & $\begin{array}{l}1.40^{\mathrm{b}} \\
\pm 0.13\end{array}$ & $\begin{array}{l}0.68^{c} \\
\pm 0.10\end{array}$ & $\begin{array}{l}2.28^{a} \\
\pm 0.38\end{array}$ & $\begin{array}{l}1.74 \mathrm{ab} \\
\pm 0.28\end{array}$ & $\begin{array}{l}1.33 \mathrm{bc} \\
\pm 0.39\end{array}$ & $\begin{array}{l}0.71^{\mathrm{c}} \\
\pm 0.12\end{array}$ & $\begin{array}{l}2.13^{\mathrm{a}} \\
\pm 0.10\end{array}$ & $\begin{array}{l}2.03^{\mathrm{a}} \\
\pm 0.01\end{array}$ & $\begin{array}{l}1.69^{\mathrm{b}} \\
\pm 0.06\end{array}$ & $\begin{array}{l}1.14^{\mathrm{c}} \\
\pm 0.04\end{array}$ \\
\hline $\begin{array}{c}\text { Root dry } \\
\text { weight }(\mathrm{g})\end{array}$ & $\begin{array}{l}0.29^{\mathrm{a}} \\
\pm 0.04\end{array}$ & $\begin{array}{l}0.24^{\mathrm{ab}} \\
\pm 0.05\end{array}$ & $\begin{array}{l}0.21^{\mathrm{ab}} \\
\pm 0.05\end{array}$ & $\begin{array}{l}0.14^{\mathrm{b}} \\
\pm 0.01\end{array}$ & $\begin{array}{l}0.21^{\mathrm{b}} \\
\pm 0.05\end{array}$ & $\begin{array}{l}0.28^{\mathrm{b}} \\
\pm 0.02\end{array}$ & $\begin{array}{l}0.22^{\mathrm{b}} \\
\pm 0.05\end{array}$ & $\begin{array}{l}0.13^{\mathrm{b}} \\
\pm 0.04\end{array}$ & $\begin{array}{l}0.32^{\mathrm{a}} \\
\pm 0.01\end{array}$ & $\begin{array}{l}0.24^{\mathrm{b}} \\
\pm 0.02\end{array}$ & $\begin{array}{l}0.19^{\mathrm{c}} \\
\pm 0.01\end{array}$ & $\begin{array}{l}0.12^{\mathrm{d}} \\
\pm 0.01\end{array}$ \\
\hline $\begin{array}{l}\text { Shoot } \\
\text { length } \\
(\mathrm{cm})\end{array}$ & $\begin{array}{l}12.87^{\mathrm{a}} \\
\pm 1.60\end{array}$ & $\begin{array}{l}8.97^{\mathrm{b}} \\
\pm 0.98\end{array}$ & $\begin{array}{l}7.80^{b} \\
\pm 0.26\end{array}$ & $\begin{array}{l}7.33^{\mathrm{b}} \\
\pm 0.74\end{array}$ & $\begin{array}{l}26.17^{\mathrm{a}} \\
\pm 2.99\end{array}$ & $\begin{array}{l}21.23^{\mathrm{a}} \\
\pm 0.91\end{array}$ & $\begin{array}{l}21.77^{a} \\
\pm 0.15\end{array}$ & $\begin{array}{l}20.80^{\mathrm{a}} \\
\pm 1.05\end{array}$ & $\begin{array}{l}27.73^{a} \\
\pm 3.46\end{array}$ & $\begin{array}{l}24.00^{\mathrm{a}} \\
\pm 1.48\end{array}$ & $\begin{array}{l}23.00^{\mathrm{a}} \\
\pm 0.64\end{array}$ & $\begin{array}{r}24.53^{\mathrm{a}} \\
\pm 0.82\end{array}$ \\
\hline $\begin{array}{l}\text { Root } \\
\text { length } \\
(\mathrm{cm})\end{array}$ & $\begin{array}{l}11.43^{\mathrm{a}} \\
\pm 2.05\end{array}$ & $\begin{array}{l}7.33^{a} \\
\pm 0.33\end{array}$ & $\begin{array}{l}13.73^{\mathrm{a}} \\
\pm 4.09\end{array}$ & $\begin{array}{l}11.40^{\mathrm{a}} \\
\pm 2.94\end{array}$ & $\begin{array}{l}12.43^{\mathrm{a}} \\
\pm 2.49\end{array}$ & $\begin{array}{l}10.60^{\mathrm{a}} \\
\pm 3.63\end{array}$ & $\begin{array}{l}11.77^{\mathrm{a}} \\
\pm 3.72\end{array}$ & $\begin{array}{l}13.23^{\mathrm{a}} \\
\pm 2.95\end{array}$ & $\begin{array}{l}14.70^{\mathrm{a}} \\
\pm 2.59\end{array}$ & $\begin{array}{l}8.90^{\mathrm{a}} \\
\pm 2.28\end{array}$ & $\begin{array}{l}5.77^{\mathrm{a}} \\
\pm 1.19\end{array}$ & $\begin{array}{l}11.87^{\mathrm{a}} \\
\pm 2.76\end{array}$ \\
\hline
\end{tabular}

Each value is across $n$ number of replicates $(n=3)$. Mean values for species and Ni levels marked with the same letter did not differ significantly at $5 \%$ level of probability by multiple comparisons (Duncan's multiple range test) elucidated after two-way ANOVA, with significant variability among species and Ni levels.

Table 2. Values and significance of correlation coefficient $(r)$ by $t$-test for morpho-biochemical expressions, macronutrients, stress marker (MDA), antioxidant enzymes and Ni levels (10-40 $\left.\mu \mathrm{g} \mathrm{kg}{ }^{-1}\right)$ in tissues (leaves and roots) of three minor fruit species (Grewia asiatica L., Syzgium cumini (L.) Skeels and Tamarindus indica L.).

(a)

\begin{tabular}{|c|c|c|c|}
\hline Attributes & G. asiatica L. & S. cumini (L.) Skeels & T. indica $\mathrm{L}$. \\
\hline Shoot fresh weight (g) & -0.48 & -0.32 & -0.44 \\
\hline Shoot dry weight (g) & $-0.71 *$ & $-0.67 *$ & -0.70 * \\
\hline Root fresh weight (g) & -0.45 & -0.38 & -0.32 \\
\hline Root dry weight (g) & $-0.54 *$ & $-0.51 *$ & $-0.61 *$ \\
\hline Shoot length (g) & -0.33 & -0.41 & -0.39 \\
\hline Root length (g) & -0.51 & -0.56 & -0.55 \\
\hline Leaf number & 0.48 & 0.42 & 0.35 \\
\hline Leaf area $\left(\mathrm{cm}^{2}\right)$ & 0.38 & 0.40 & 0.53 \\
\hline Chlorophyll $a\left(\mu \mathrm{g} \mathrm{g}^{-1} \mathrm{FW}\right)$ & -0.36 & -0.44 & -0.47 \\
\hline Chlorophyll $b\left(\mu \mathrm{g} \mathrm{g}^{-1} \mathrm{FW}\right)$ & -0.22 & -0.29 & -0.33 \\
\hline
\end{tabular}

(b)

\begin{tabular}{|c|c|c|c|c|c|c|}
\hline Tissues & Leaves & Roots & Leaves & Roots & Leaves & Roots \\
\hline $\mathrm{Na}^{+}\left(\mathrm{mg} \mathrm{kg}^{-1}\right)$ & -0.21 & -0.32 & -0.32 & -0.21 & -0.30 & -0.19 \\
\hline $\mathrm{K}^{+}\left(\mathrm{mg} \mathrm{kg}^{-1}\right)$ & -0.39 & -0.36 & -0.31 & -0.23 & -0.26 & -0.21 \\
\hline $\mathrm{Ca}^{2+}\left(\mathrm{mg} \mathrm{kg}^{-1}\right)$ & -0.36 & -0.33 & -0.49 & $-0.56 *$ & -0.22 & -0.24 \\
\hline $\mathrm{Mg}^{2+}\left(\mathrm{mg} \mathrm{kg}^{-1}\right)$ & $0.62 *$ & 0.44 & 0.51 & 0.38 & 0.41 & 0.29 \\
\hline MDA ( $\mu$ mol mg ${ }^{-1}$ protein) & 0.31 & 0.38 & 0.26 & 0.32 & 0.24 & 0.29 \\
\hline $\mathrm{SOD}\left(\mathrm{U} \mathrm{mg}^{-1}\right.$ protein $)$ & 0.25 & 0.47 & 0.21 & 0.34 & 0.21 & 0.38 \\
\hline CAT (U mg ${ }^{-1}$ protein) & 0.37 & 0.48 & 0.23 & 0.29 & 0.57 * & 0.67 * \\
\hline POD (U mg ${ }^{-1}$ protein) & $0.71 *$ & $0.67 *$ & 0.46 & 0.52 & 0.51 & 0.62 * \\
\hline
\end{tabular}

$*$ significant at $0.05 \%$ level of probability by student's $t$-test ( $\mathrm{df}=n-2$ and $n=9)$. The values of $r$ without * superscript are not significant, both for positive and negative correlations. 


\subsection{Photosynthetic Apparatus}

For leaf number and area (Figure 1a,b), the species showed a marked disparity at all levels of Ni. Among species, S. cumini, had a lower mean (9.58) leaf number, but T. indica exhibited a greater leaf area $\left(18.28 \mathrm{~cm}^{2}\right)$ at $40 \mu \mathrm{g} \mathrm{kg}{ }^{-1} \mathrm{Ni}$. The decline in leaf number was not as pronounced in the species, as Ni levels did not show any significant variability. For leaf area, the species exhibited significant $(p \leq 0.01)$ responses, but Ni levels were found to be insignificantly variable.

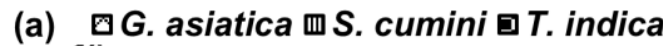

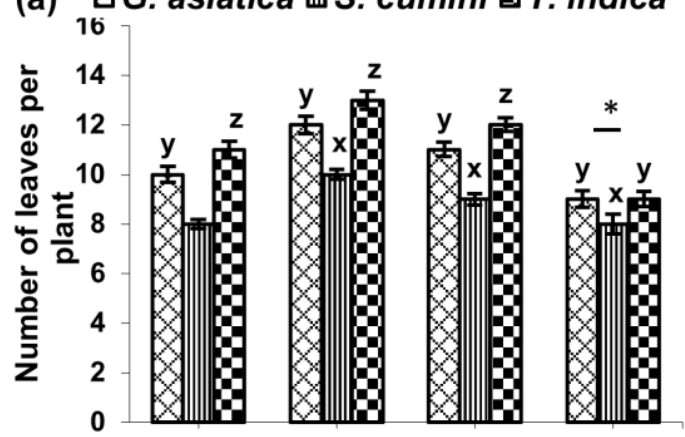

(c)

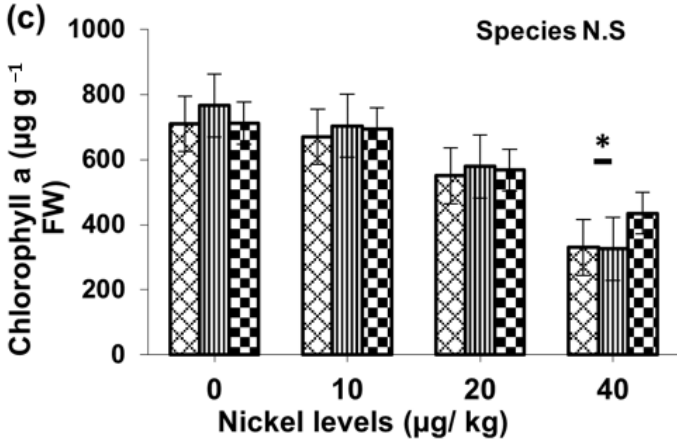

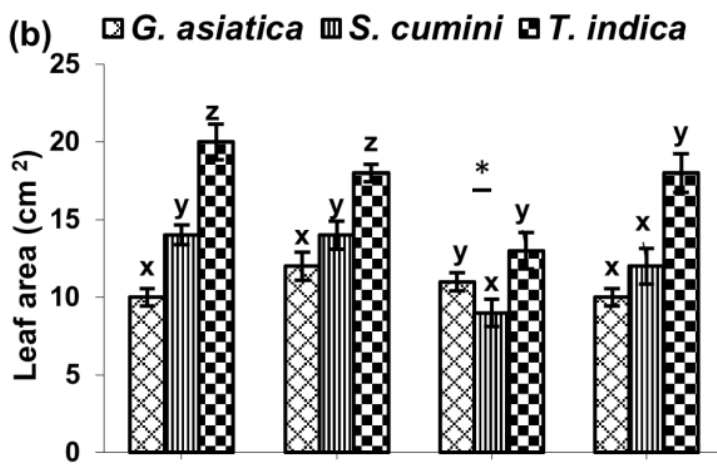

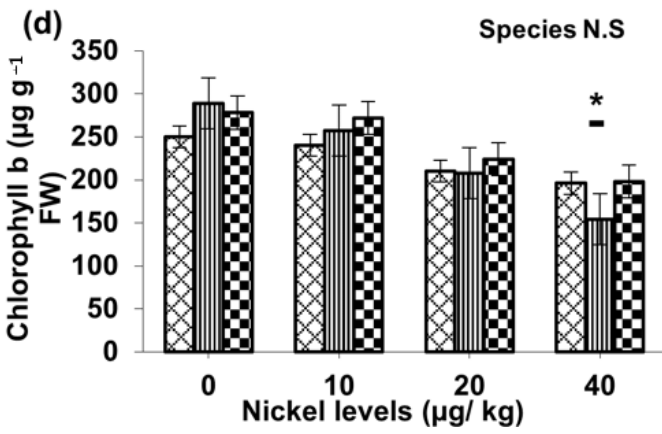

Figure 1. Photosynthetic attributes: leaf number (a), leaf area $(\mathbf{b})$, chlorophyll a (c) and chlorophyll b (d) in three minor fruit species (Grewia asiatica L., Syzgium cumini (L.) Skeels and Tamarindus indica L.) after exposure to increasing levels of $\mathrm{Ni}$ in the growth medium. Each mean is across three replicates with \pm S.E. Different letters on each bar indicate significant difference between species $(x-z)$, and ${ }^{*}$ on each level shows a marked variability from the control, analyzed through two-factor ANOVA, with equal number of replications, followed by a post hoc multiple comparison test (DMRT).

The highest Ni level induced a more profound (up to 57\%) decline in chlorophyll a in G. asiatica and S. cumini, while the reverse was true for T. indica, which had greater contents of chlorophyll a (Figure 1c). The reduction in chlorophyll b was less than that in chlorophyll $a$ in all species except in S. cumini, which exhibited the most profound reduction $(45 \%)$ at the highest level of $\mathrm{Ni}$, as compared to G. asiatica and T. indica, which exhibited reductions of almost 20 and $26 \%$ in chlorophyll $b$ content, respectively (Figure $1 \mathrm{~d}$ ). Although increasing levels of Ni prompted a decline in the contents of chlorophyll a and $b$ in all species as compared to their respective control plants, responses of the species were found to be insignificantly variable. Only the highest level of Ni showed a significant $(p \leq 0.05)$ contrast from other levels of Ni. The leaf number and leaf area were not found to be negatively correlated with $\mathrm{Ni}$ in tissues in all species (Table 2).

\subsection{MDA Production and Nickel Uptake in Tissues}

Since the levels of lipid peroxidation occurred in a concentration-dependent manner, the highest amount of MDA in tissues was noticed at the most elevated level of $\mathrm{Ni}$ (Figure 2a,b). S. cumini and T. indica had more profound levels of MDA in in both types of tissue (roots and leaves) after exposure to the highest levels of Ni. A significant contrast 
$(p \leq 0.01)$ between species and Ni levels became evident for this expression. The MDA contents were almost double in S. cumini and T. indica leaves at $40 \mu \mathrm{g} \mathrm{kg}^{-1}$ (Figure 2a), but the overall MDA contents were greater in the roots of the species (Figure 2b). The highest amount $\left(12.3 \mathrm{mmol}^{-1} \mathrm{~cm}^{-1}\right)$ was noticed for S. cumini, followed by T. indica $\left(10.4 \mathrm{mmol}^{-1} \mathrm{~cm}^{-1}\right)$, whereas G. asiatica had the lowest $\left(7.2 \mathrm{mmol}^{-1} \mathrm{~cm}^{-1}\right)$ amount of MDA at the most elevated levels of Ni. The most profound surge (60 and 70\%) in MDA was noted in G. asiatica roots at 10 and $20 \mu \mathrm{g} \mathrm{kg}^{-1} \mathrm{Ni}$, compared to the corresponding control plants. The significantly $(p \leq 0.01)$ variable responses of the species after $\mathrm{Ni}$ exposure in both tissues became evident. The overall Ni contents in the leaves were comparably lower (Figure 2c) than the metal contents of the roots (Figure 2d) in all species. The bioaccumulation of $\mathrm{Ni}$ in the roots of G. asiatica was the highest after exposure to $40 \mu \mathrm{g} \mathrm{kg}^{-1}$, as compared to other species. However, T. indica had 40,45 and $52 \%$ more Ni in leaves at 10, 20 and $40 \mu \mathrm{g} \mathrm{kg}^{-1} \mathrm{Ni}$, respectively, than control plants. The responses of species varied significantly $(p \leq 0.001)$ for $\mathrm{Ni}$ in leaves. Moreover, species and Ni levels showed a marked $(p \leq 0.05)$ contrast for metal contents in roots. The Ni content in tissues rose, resulting in a greater amount of MDA, but this was not strongly positive, and hence was statistically non-significant (Table 2).
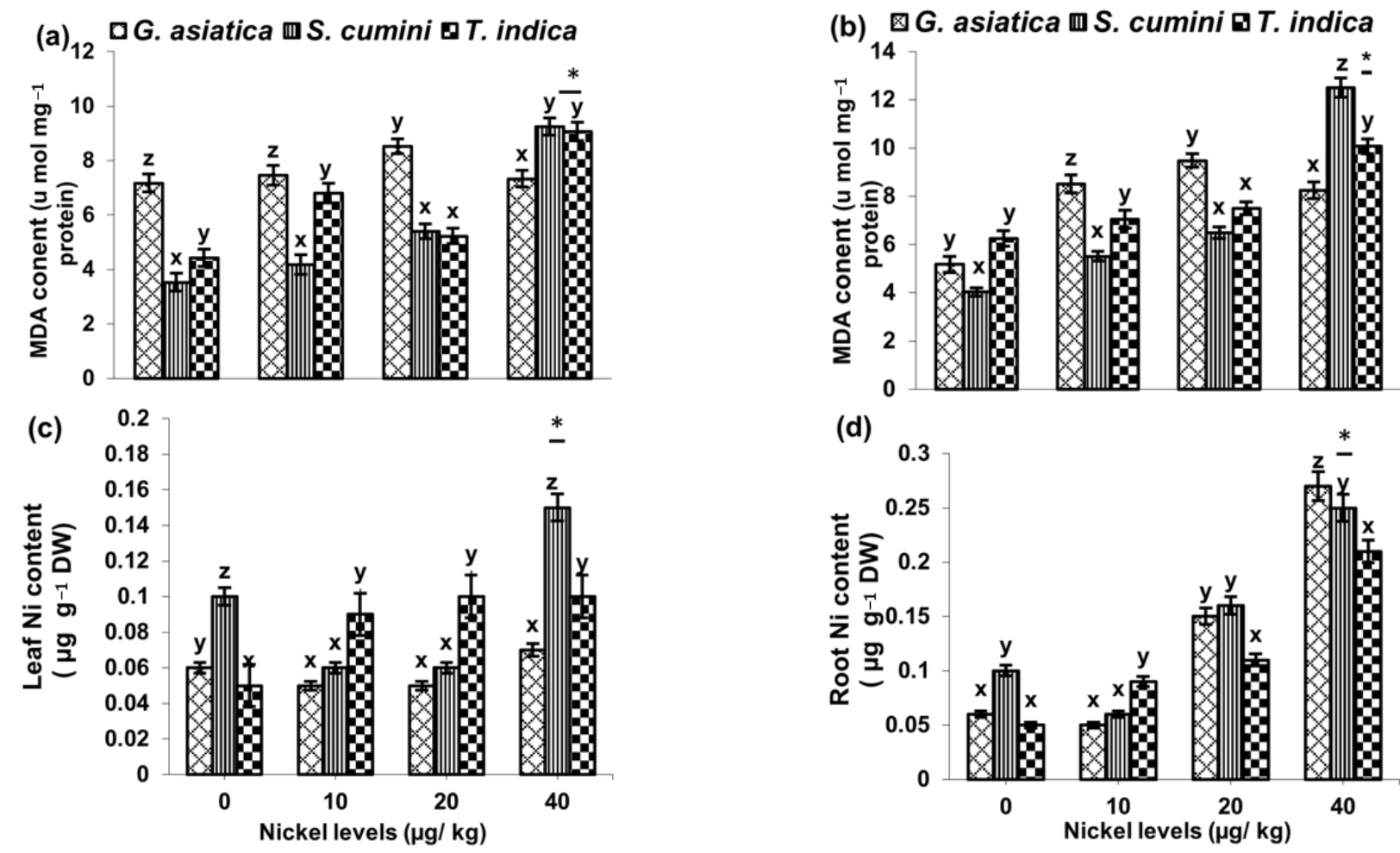

Figure 2. Malondialdehyde in leaves and roots $(\mathbf{a}, \mathbf{b})$ and bioaccumulations of $\mathrm{Ni}$ in the tissues (c,d) of three minor fruit species (Grewia asiatica L., Syzgium cumini (L.) Skeels and Tamarindus indica L.) after exposure to increasing levels of $\mathrm{Ni}$ in the growth medium. Each mean is across three replicates with \pm S.E. Different letters on each bar indicate significant difference between species $(x-z)$, and * on each level shows a marked variability from the control, analyzed through two-factor ANOVA, with equal number of replications, followed by a post hoc multiple comparison test (DMRT).

\subsection{Nutritional Status of Species for Macronutrients}

Both leaf and root sodium (Figure 3a,b) exhibited a steady decline with increasing $\mathrm{Ni}$ concentrations in the species. The maximum concentrations of ions were recorded in control plants of all three species. Exposure to Ni levels induced a similar pattern of reduction in all species, whereby a progressive reduction was noticed with increasing concentrations of the metal. S. cumini consistently had more leaf $\mathrm{Na}^{+}\left(11.2,9.8,9.6 \mathrm{mg} \mathrm{kg}^{-1}\right.$ 
DW) at 10, 20 and $40 \mu \mathrm{g} \mathrm{kg}^{-1}$ of Ni, respectively, followed by T. indica (Figure 3a). The $\mathrm{K}^{+}$content of the leaves (Figure 3c) exhibited a significant decline in all species at greater $\mathrm{Ni}$ levels. The reduction of the $\mathrm{K}^{+}$ions in the roots (Figure 3d) was almost two-fold in all species, but G. asiatica had significantly more $\mathrm{K}^{+}$at all levels of Ni. The responses of S. cumini and T. indica were almost comparable in both tissues. The species and Ni levels showed significant $(p \leq 0.05)$ variability for $\mathrm{Na}^{+}$and $\mathrm{K}^{+}$contents in both tissues. The non-affirmative relationship between the Ni contents and elemental levels in both tissues was found to be insignificant (Table 2). The calcium content in the species decreased with ascending Ni levels, but a more extreme reduction (55\%) was noticed in the leaves of $T$. indica at the most elevated Ni level, as compared to respective control plants (Figure 3e). However, G. asiatica and S. cumini did not show much variability for leaf $\mathrm{Ca}^{2+}$ at all Ni levels. S. cumini had more calcium in roots at all levels of Ni (Figure 3f), followed by G. asiatica. The species varied markedly for the calcium content in leaves and roots, with a considerable influence of $\mathrm{Ni}$ on calcium levels in the tissues. A non-linear relationship between $\mathrm{Ni}$ in tissues and a decline in calcium content of both roots and leaves became evident (Table 2). However, a significant $(p \leq 0.05)$ positive correlation became evident for root calcium in S. cumini and Ni levels in the tissue (Table 2). Ni applications did not cause any profound decline in the magnesium content in the leaves of all species, but G. asiatica had more magnesium at all levels of Ni, followed by T. indica (Figure 3g). A significant $(p \leq 0.01)$ variability between species became evident only for leaf magnesium. G. asiatica also had a greater magnesium content in roots, followed by S. cumini; hence, T. indica exhibited the lowest magnesium content at the most elevated level of Ni (Figure 3h). Moreover, a significant $(p \leq 0.05)$, linear degree of association between leaf $\mathrm{Mg}$ and $\mathrm{Ni}$ contents in the leaves was observed in G. asiatica (Table 2).

\subsection{Antioxidant Enzymes (SOD, CAT and POD)}

An increase in SOD activity was observed in the leaves and roots (Figure $4 a, b$ ) of all species in relation to increasing levels of Ni. However, the activity of SOD was much greater in the roots as compared to leaves. The alteration in the activity of SOD was more vigorous in the leaves of G. asiatica, which showed a $55 \%$ rise, while T. indica had about $23 \%$ enhanced activity of SOD relative to its respective control plants at $40 \mu \mathrm{g} \mathrm{kg}{ }^{-1} \mathrm{Ni}$. No intense change in SOD activity was observed in the roots of the species; hence, significantly $(p \leq 0.01)$ variable responses for SOD activity were noticed for leaves only. All species had shown a linear increase in SOD with increasing Ni contents for both tissues but this relationship was found to be statistically non-significant (Table 2). A gradual increase in CAT activity was noted in the leaves of the species (Figure 4c) after exposure to $\mathrm{Ni}$ but a stronger activity was observed in the roots of T. indica at $40 \mu \mathrm{g} \mathrm{kg}^{-1} \mathrm{Ni}$ (Figure $4 \mathrm{~d}$ ). The species had shown a significant contrast for the activity of CAT in both tissues; however, the application of Ni more profoundly $(p \leq 0.01)$ affected the activity in roots than leaves. The increase in CAT activity continued with increasing Ni levels in T. indica followed by S. cumini and G. asiatica at 20 and $40 \mu \mathrm{g} \mathrm{kg}^{-1} \mathrm{Ni}$. An enhanced activity of CAT was also noticed in the roots of G. asiatica at 10, 20 and $40 \mu \mathrm{g} \mathrm{kg}^{-1} \mathrm{Ni}$ but $T$. indica uniformly had more pronounced activity in the roots at all levels of Ni (Figure $4 \mathrm{~d}$ ). The trends regarding an increase in CAT activity were found to be assenting with increasing levels of $\mathrm{Ni}$ in tissues but significant for T. indica only (Table 2). Figure 4e depicts the homogenously greater POD activity in the leaves of G. asiatica in response to different Ni levels. A gradual increase in POD activity was also noticed in the roots of the species with increasing $\mathrm{Ni}$ levels (Figure 4f), but G. asiatica roots showed the highest rise in POD at all levels of Ni. The responses of species for both tissues were found to be statistically highly significant ( $p \leq 0.001$ for leaves and $p \leq 0.01$ for roots). Similarly, Ni levels also exhibited a marked contrast for both tissues $(p \leq 0.05)$. An overall greater activity of POD was noticed in the foliage of the three species than roots. The trends between Ni levels in tissues and POD were found to be significantly affirmative for G. asiatica and only for roots in T. indica (Table 2). 

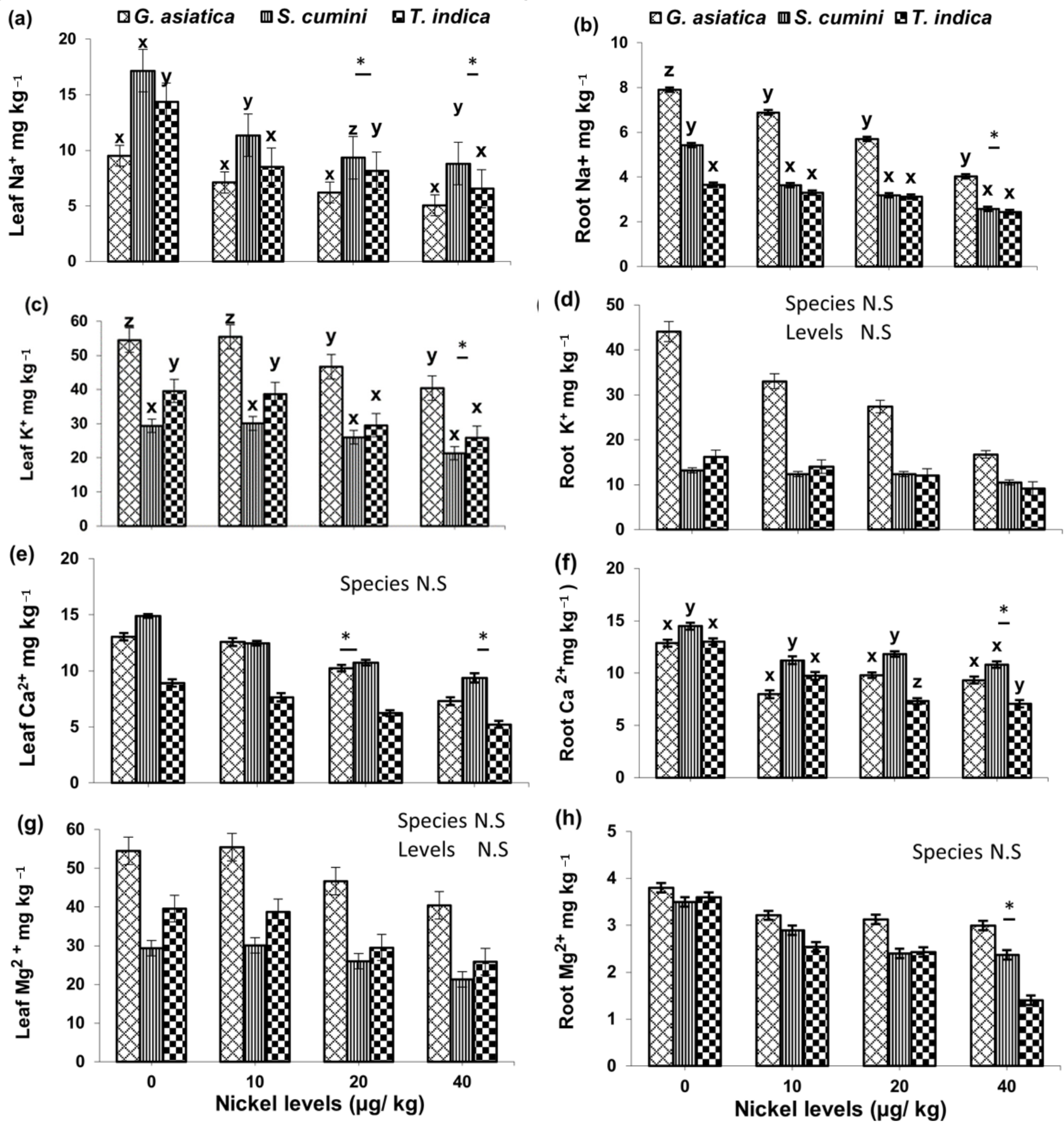

Figure 3. Macronutrient $\mathrm{Na}^{+}, \mathrm{K}^{+}, \mathrm{Ca}^{2+}$ and $\mathrm{Mg}^{2+}$ status in leaves $(\mathbf{a}-\mathbf{d})$ and roots $(\mathbf{e}-\mathbf{h})$ in three minor fruit species (Grewia asiatica L., Syzgium cumini (L.) Skeels and Tamarindus indica L.) after exposure to increasing levels of $\mathrm{Ni}$ in the growth medium. Each mean is across three replicates with \pm S.E. Different letters on each bar indicate significant difference between species $(x-z)$, and * on each level shows a marked variability from the control, analyzed through two-factor ANOVA, with equal number of replications, followed by a post hoc multiple comparison test (DMRT). 
(a)

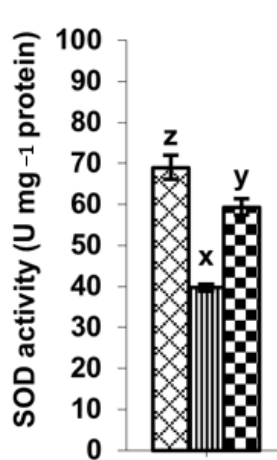

$(c)^{16}$

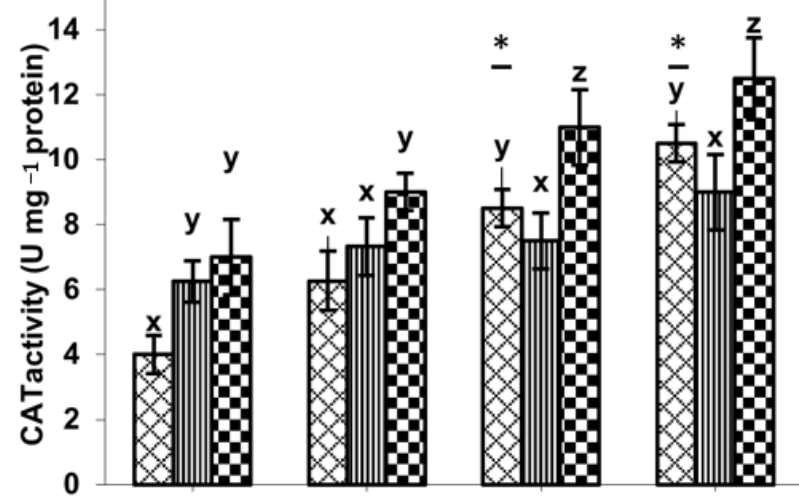

(e)

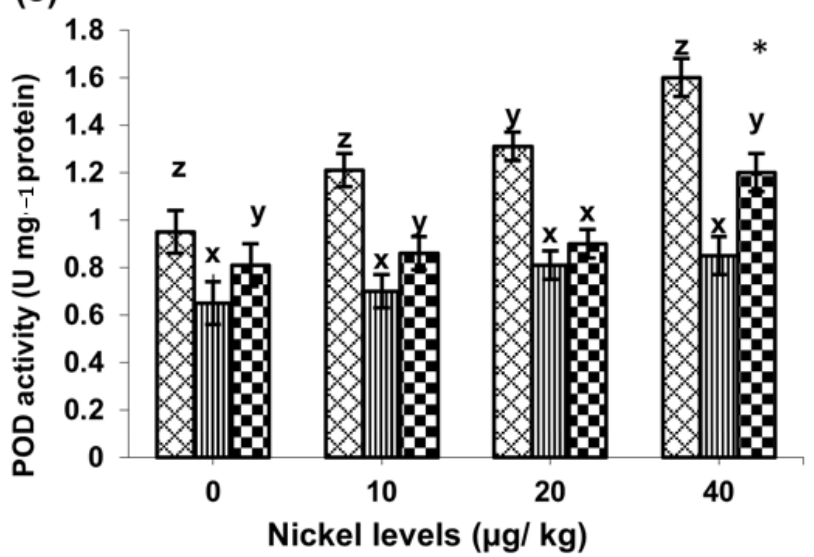

(b) $225 \quad \square$ G. asiatica mS. cumini $\square T$. indica

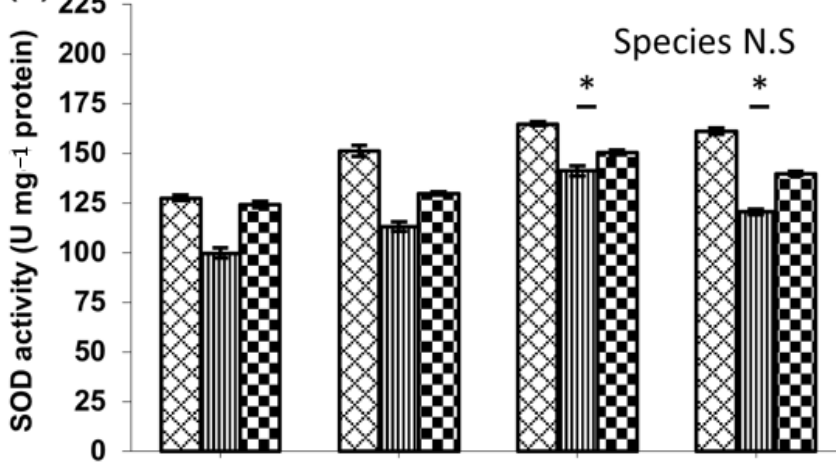

(d)

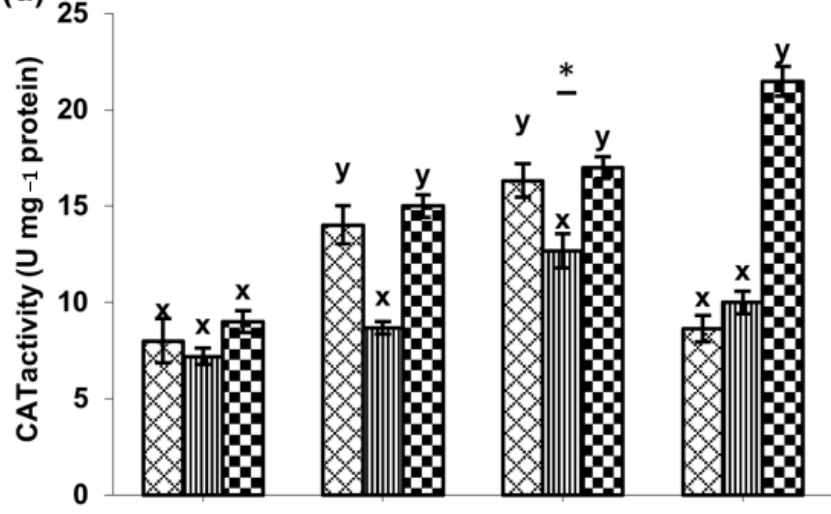

(f)

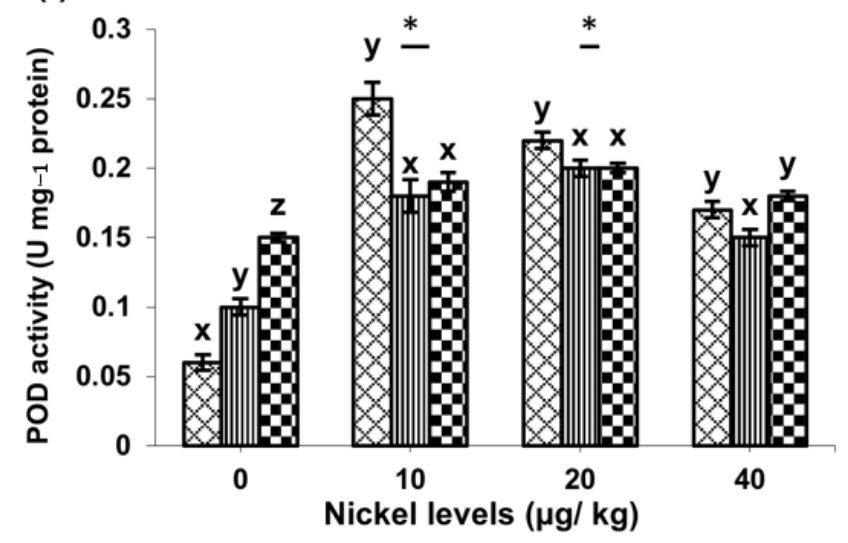

Figure 4. Activity of antioxidant enzymes SOD $(\mathbf{a}, \mathbf{b}) \operatorname{CAT}(\mathbf{c}, \mathbf{d})$ and $\operatorname{POD}(\mathbf{e}, \mathbf{f})$ in leaves and roots of three minor fruit species (Grewia asiatica L., Syzgium cumini (L.) Skeels and Tamarindus indica L.) after exposure to increasing levels of $\mathrm{Ni}$ in the growth medium. Each mean is across three replicates with \pm S.E. Different letters on each bar indicate significant difference between species $(x-z)$ and * on each level shows a marked variability from the control analyzed through two-factor ANOVA, with equal number of replications, followed by a post hoc multiple comparison test (DMRT).

\section{Discussion}

\subsection{Response of Growth and Photosynthesis}

The supra-optimal uptake and bioaccumulation of $\mathrm{Ni}$ in plant tissues and organs adversely affect essential physiological processes. Retardation in growth, modulations of pigments and lipid peroxidation have been widely documented for Ni toxicity in various plant species [32]. The current study reveals a considerable decline in various growth components of the three studied species. The inhibitory effects of $\mathrm{Ni}$ became evident for the dry biomass of the two tissues but were more profound for roots. The reason for this 
is that the roots are always directly exposed to metal ions present in the growth medium. Furthermore, apoplastic transport and accumulation of metal ions impede growth [33]. The inhibition of cell division and elongation results in less proliferation, which directly affects root morphology and, subsequently, water and mineral transport to aerial tissues. A correlation analysis of $\mathrm{Ni}$ bioaccumulation in roots and leaves with various growth components also confirmed the negative impact of $\mathrm{Ni}$ on various root and shoot growth parameters. The results of our study of growth components in relation to $\mathrm{Ni}$ application are in close agreement with many other findings for a number of other edible fruit and tree species [34,35].

The photosynthetic machinery of plants is comprised of leaves containing important biomolecules called chlorophylls, whereby leaf number, area and chlorophyll (foliage attributes) appear to be correlated traits [36]. However, no such correlation was observed in this study. The species under investigation belong to different taxonomic groups and therefore possess different characteristic foliage attributes. Therefore, leaf morphology appears to be a genetic expression, which is less liable to alter, unlike plastic characters that change under different environmental conditions [36].

Metal ions can impact the metabolism/altered biosynthesis or degradation of pigment biomolecules. This has been thought to be one of the major reasons for the impairment of photosynthesis and inhibition of growth in plants under metal stress [37]. Photosynthesis is a fundamental process that essentially requires chlorophyll for net carbon assimilation. Previous findings have documented a significant degradation of chlorophyll and inhibition of photosynthesis under excessive metal ions [38]. Downregulated chlorophyll levels possibly result from degradation or hampered biosynthesis after exposure to heavy metals. However, our results support that the bioavailability of magnesium, which is a central part of the tetrapyrrole ring of the chlorophyll molecule, can enhance overall chlorophyll content under sustainable Mg uptake [39].

\subsection{ROS Production and Antioxidant Activity}

The superoxide radical $\left(\mathrm{O}^{2-}\right)$, hydrogen peroxide $\left(\mathrm{H}_{2} \mathrm{O}_{2}\right)$, hydroxyl radical $(\mathrm{HO})$ and singlet oxygen $\left({ }^{1} \mathrm{O}_{2}\right)$ are jointly known as ROS [11], which can deteriorate all types of biomolecules and cellular entities, leading to irreversible destruction and, eventually, cell death [40]. MDA levels profoundly increased in both tissues of all species following exposure to Ni. Hence, increased free-radical generation promotes MDA production in plants under Ni stress, as reported for other higher plants [41]. An enhanced level of MDA was noticed in the roots of S. cumini and T. indica; however, the amount of MDA was lower in G. asiatica despite the greater bioaccumulation of $\mathrm{Ni}$ in tissues. Hence, the noxious effects of heavy metals initially developed through free-radical generation, but lower levels of MDA in tissues of G. asiatica serve as an indication of some underlying oxidative defense mechanism [42,43]. Yet, the bioaccumulation of $\mathrm{Ni}$ in the tissues signifies the high mobility of the $\mathrm{Ni}$ ions and the capacity of this species to store metal [44].

The decline in SOD activity only at the lowest Ni levels in leaves indicates that the oxygen-scavenging function was reduced, probably because of the lower amount of Ni not being enough to initiate an antioxidative response. On the other hand, the SOD activity in roots peaked at higher levels of $\mathrm{Ni}$, suggesting better protection against oxidative damage in roots. However, the sequence response of antioxidative defense has received much attention [45] because by the activity SOD, $\mathrm{H}_{2} \mathrm{O}_{2}$ can be removed upon its conversion to $\mathrm{H}_{2} \mathrm{O}$ in subsequent reactions. CAT can potentially eradicate noxious substances from cellular compartments because it directly removes $\mathrm{H}_{2} \mathrm{O}_{2}$ by its cleavage into water and oxygen. The capacity of POD in $\mathrm{H}_{2} \mathrm{O}_{2}$ scavenging is proved to be much greater than CAT because of its high substrate affinity [46]. Therefore, CAT remains not too strong to increase protection; hence, the main response is acquired through the enhanced activities of SOD and POD, as described by [47]. CAT activity was higher in the leaves but the higher SOD and CAT activities in G. asiatica and T. indca indicated a more effective $\mathrm{H}_{2} \mathrm{O}_{2}$ scavenging capacity. Hence, the coordinated activity of SOD and CAT might play a better protective 
role in the elimination of $\mathrm{O}_{2-}$ and $\mathrm{H}_{2} \mathrm{O}_{2}$. Several studies for a number of plants have reported increases, decreases and no changes in POD activity following exposure to heavy metals [45,47]. Nevertheless, POD is a ubiquitously distributed enzyme of all plant species involved in the removal of ROS [48]. Thus, resilient species can maintain high levels of POD activity in response to more toxic levels of heavy metals. Moreover, POD contributes towards lignin biosynthesis and thus stronger wall barriers against toxic metal ions. Thus, enhanced POD activity in G. asiatica seems to be more efficient in avoiding metal toxicity and subsequent damage.

\subsection{Nutrient Uptake and Ni Toxicity}

An increase in mineral nutrient ions $\left(\mathrm{Na}^{+}, \mathrm{K}^{+}, \mathrm{Ca}^{2+}\right.$ and $\left.\mathrm{Mg}^{2+}\right)$ is believed to be a crucial mechanism for plants to resist to stress [49]. In the present investigation, variation occurred in the transport of these elements in plants subjected to Ni stress. $\mathrm{Na}^{+}$is the main element for maintaining the turgor of plant cells but increasing Ni levels induced more alterations in the roots because of their direct contact with metal. The possible decline in $\mathrm{Na}^{+}$likely occurs due to substitution or reduced uptake from the medium in the presence of elevated Ni levels [50].

Similarly, a decline in the $\mathrm{K}^{+}$content in roots of the species might occur due to reduced uptake, or rapid translocation to aerial tissues in the presence of $\mathrm{Ni}$, as described by Maathuis [44]. Ni can substantially alter soil property and restrict the uptake of many essential mineral ions. Thus, a negative impact on $\mathrm{K}^{+}$ions is likely under higher Ni levels in the soil (Ishtiaq et al. 2014). Further, Ni has the ability to compete with ions such as $\mathrm{K}^{+}$, which in turn acquire a regulatory control on its uptake [51,52]. Nevertheless, the physiological implication of more $\mathrm{K}^{+}$in roots and sustainable transport to leaves seems to be a selective advantage in G. asiatica. Among macronutrients, $\mathrm{Ca}^{2+}$ is also of fundamental importance because it is a main constituent of the plant cell wall. The thickness and strength of cells and tissues directly correlate with the amount of wall material (calcium pectate). A sharp decline in the $\mathrm{Ca}^{2+}$ content of plant tissues in relation to the supra-optimal concentration of $\mathrm{Ni}$ has been previously reported [53]. The displacement of $\mathrm{Ca}^{2+}$ from exchange sites by metal ions was described as the reason of this decline, but when $\mathrm{Ca}^{2+}$ remains strongly bound to the root in free space, the root walls will be strong [54]. G. asiatica and S. cumini exhibited more calcium in their roots as compared to foliage, hence signifying the robust cell walls of the tissue. No impairment was observed in the uptake and distribution of $\mathrm{Mg}^{2+}$ in foliage as the levels of this essential nutrient remained high as compared to roots. A steady uptake of $\mathrm{Mg}^{2+}$ became evident in species irrespective of the amount of $\mathrm{Ni}$ in the soil. Among mobile elements, $\mathrm{Mg}^{2+}$ easily translocates within and between the cells and tissues of plants. However, its transport to aerial tissues, particularly in the leaves is of great functional significance, because it is an integral/ central part of the chlorophyll molecule. The substantial amount of $\mathrm{Mg}^{2+}$, particularly in leaves, implies some resilience of plants due to photosynthetic apparatus, as proposed by Bloom [55]. Moreover, a negligible reduction in chlorophyll $\mathrm{b}$ in all species exhibited an affirmative relation between $\mathrm{Mg}^{2+}$ and the sustainable biosynthesis of photosynthetic molecule.

The decline in SOD activity only at the lowest $\mathrm{Ni}$ levels in leaves indicated that the oxygen-scavenging function was reduced probably because of the lower amount of $\mathrm{Ni}$ that was not enough to initiate the antioxidative response. On the other hand, SOD activity in roots peaked at higher levels of $\mathrm{Ni}$, suggesting a better protection against oxidative damage in roots. However, the sequence response of antioxidative defense has received much attention [15] because with SOD activity, $\mathrm{H}_{2} \mathrm{O}_{2}$ can be removed by its conversion to $\mathrm{H}_{2} \mathrm{O}$ in subsequent reactions. CAT can potentially eradicate noxious substances from cellular compartments because it directly removes $\mathrm{H}_{2} \mathrm{O}_{2}$ by its cleavage into water and oxygen. The capacity of POD in $\mathrm{H}_{2} \mathrm{O}_{2}$ scavenging is proven to be much greater than that of CAT because of its high substrate affinity [19]. Therefore, CAT does not play some protective role hence, the main response is acquired through enhanced SOD and POD activities, as described in [46]. CAT activity was greater in the leaves, but the higher SOD and CAT activities in G. 
asiatica and T. indca indicate a more effective $\mathrm{H}_{2} \mathrm{O}_{2}$-scavenging capacity. Hence, coordinated activity of SOD and CAT might play a better protective role in the elimination of $\mathrm{O}_{2-}$ and $\mathrm{H}_{2} \mathrm{O}_{2}$. Several studies of a number of plants reported increases, decreases and no changes in POD activity following exposure to heavy metals $[13,15]$. Nevertheless, POD enzymes are ubiquitously distributed in all plant species and are involved in the removal of ROS [52]. Thus, metal resilient species can maintain high levels of POD activity in response to more toxic levels of heavy metals. Moreover, POD contributes to lignin biosynthesis and thus stronger wall barriers against toxic metal ions. Thus, enhanced POD activity in G. asiatica seems to be more efficient with regard to avoiding metal toxicity and subsequent damage.

Plants, including tree species, respond to stress through alterations in morphological and physiological expressions during particular phases of development: juvenile vegetative growth to the adult stage. Most metals more readily translocate from roots to above-ground tissues in young saplings than in adult woody plants [56]. Better acclimation and adaptation have been reported with the age of trees and many other physiological processes for the restricted transfer of metals [56]. Additionally, the branching architecture, slower growth rates, longer reproductive cycles and different nature of hormonal control at adult stages are considered as key factors for resilience in response to heavy metal stress more so in adult trees than their seedlings [57].

\section{Conclusions}

From the present study, it can be concluded that elevated Ni in the growth medium negatively altered the growth components of the three studied species. Among various growth expressions, the dry weight of tissues served as one of the realistic predictors because it represents a cumulative outcome of various underlying processes in relation to abiotic stresses, including heavy metals. Hence, Ni induced a more drastic decline in the dry biomass production of these species. Foliage traits appear to be less vulnerable to Ni. Chloroplast and pigment molecules appear to be of a robust nature in the studied species. The species showed differential capacities for the uptake, transport and bioaccumulation of $\mathrm{Ni}$ in both above- and below-ground tissues. However, this occurred in a concentrationdependent manner. Ni induced elevated production of ROS via lipid peroxidation; then, a defensive mechanism was triggered by the action of antioxidant enzymes. The sequential activation of these enzymes assisted with the scavenging of free radicals generated in plants following exposure to Ni. However, the activity of antioxidant enzymes varied markedly in the two tissues. The greater activity of POD, as compared to SOD and CAT, in the leaves suggests POD as an effective quencher to $\mathrm{H}_{2} \mathrm{O}_{2}$, which compensates for the inadequate activity of SOD and CAT. Thus, the protection and mitigation of oxidative stress of photosynthetic machinery seems to lead to better resilience in the species in order to alleviate the detrimental effects of Ni. This study further signified that species responded in an manner independent to metal levels, and each expression showed a differential pattern of variability. An intrinsic resilience of G. asiatica seems to be achieved by having more calcium in its roots, greater magnesium in its leaves and a restricted transport of metal to foliage, along with greater activities of SOD and CAT in the roots and enhanced POD in leaves in a sequential manner and therefore a capacity of the species to evolve under selection pressures imposed by excessive Ni in soil. The evolution potential of the studied species can be employed for the economic utilization of metal-contaminated soils.

Author Contributions: Conceptualization, S.Z. and S.M.; methodology, S.N.; software, R.A.; validation, A.A., S.N. and S.M.; formal analysis, S.Z.; investigation, S.Z. and R.A.; resources, S.M.; data curation, S.Z.; writing—original draft preparation, S.Z. and A.A.; writing-review and editing, S.Z., A.A.A. and T.S.; visualization, S.Z.; supervision, S.M.; project administration, S.M.; funding acquisition, A.A.A. and T.S. All authors have read and agreed to the published version of the manuscript.

Funding: This research received no external funding.

Institutional Review Board Statement: Not applicable. 
Data Availability Statement: The data supporting the conclusions of this article are included within the article. Any queries regarding these data may be directed to the corresponding author.

Acknowledgments: This manuscript is the part of Ph.D. thesis of Saman Zahra. The doctoral study and International Research Support Initiative Programme (IRSIP) of the University of Arizona, Tucson, AZ, USA, was supported by the Higher Education Commission, Islamabad, Pakistan under the Indigenous Scholarship Program Phase II. The authors would also like to extend their sincere appreciation to the researchers supporting Project Number (RSP-2021/236), King Saud University, Riyadh, Saudi Arabia.

Conflicts of Interest: The authors declare no conflict of interest.

\section{References}

1. Meshram, P.; Pandey, B.D. Advanced Review on Extraction of Nickel from Primary and Secondary Sources. Miner. Process. Extr. Met. Rev. 2018, 40, 157-193. [CrossRef]

2. Brown, L.R. A new era unfolds. Challenge 1993, 36, 37-46. [CrossRef]

3. Iyaka, Y.A. Nickel in soils: A review of its distribution and impacts. Sci. Res. Essays 2011, 6, 6774-6777.

4. Radha, T.; Mathew, L. Fruit Crops; New India Publishing: New Delhi, India, 2007; Volume 3.

5. Des, U. World Economic and Social Survey 2013: Sustainable Development Challenges; United Nations, Department of Economic and Social Affairs: New York, NY, USA, 2013; pp. 123-136.

6. Visioli, G.; Conti, F.D.; Gardi, C.; Menta, C. Germination and root elongation bioassays in six different plant species for testing Ni contamination in soil. Bull. Environ. Contam. Toxicol. 2014, 92, 490-496. [CrossRef] [PubMed]

7. Shahzad, B.; Tanveer, M.; Rehman, A.; Cheema, S.A.; Fahad, S.; Rehman, S.; Sharma, A. Nickel; whether toxic or essential for plants and environment-A review. Plant Physiol. Biochem. 2018, 132, 641-651. [CrossRef] [PubMed]

8. Kapoor, D.; Singh, M.P.; Kaur, S.; Bhardwaj, R.; Zheng, B.; Sharma, A. Modulation of the functional components of growth, photosynthesis, and anti-oxidant stress markers in cadmium Exposed Brassica juncea L. Plants 2019, 8, 260. [CrossRef]

9. Zeeshan, M.; Ahmad, W.; Hussain, F.; Ahamd, W.; Numan, M.; Shah, M.; Ahmad, I. Phytostabalization of the heavy metals in the soil with biochar applications, the impact on chlorophyll, carotene, soil fertility and tomato crop yield. J. Clean. Prod. 2020, 255, 120318-120323. [CrossRef]

10. Ashraf, M.; Harris, P.J. Photosynthesis under stressful environments: An overview. Photosynthetica 2013, 51, 163-190. [CrossRef]

11. Hall, J.L. Cellular mechanisms for heavy metal detoxification and tolerance. J. Exp. Bot. 2002, 53, 1-11. [CrossRef]

12. Matraszek, R.; Hawrylak-Nowak, B.; Chwil, S.; Chwil, M. Macronutrient composition of nickel-treated wheat under different sulfur concentrations in the nutrient solution. Environ. Sci. Pollut. Res. 2016, 23, 5902-5914. [CrossRef]

13. Bhalerao, S.A.; Sharma, A.S.; Poojari, A.C. Toxicity of nickel in plants. Int. J. Pure Appl. Biosci. 2015, 3, $345-355$.

14. Kohli, S.K.; Handa, N.; Gautam, V.; Bali, S.; Sharma, A.; Khanna, K.; Arora, S.; Thukral, A.K.; Ohri, P.; Karpets, Y.V. ROS Signaling in Plants under Heavy Metal Stress. In Reactive Oxygen Species and Antioxidant Systems in Plants: Role and Regulation under Abiotic Stress; Springer: Singapore, 2017; pp. 185-214.

15. Hasanuzzaman, M.; Bhuyan, M.; Zulfiqar, F.; Raza, A.; Mohsin, S.M.; Mahmud, J.A.; Fujita, M.; Fotopoulos, V. Reactive oxygen species and antioxidant defense in plants under abiotic stress: Revisiting the crucial role of a universal defense regulator. Antioxidants 2020, 9, 681. [CrossRef] [PubMed]

16. Abid, R.; Manzoor, M.; De Oliveira, L.M.; da Silva, E.; Rathinasabapathi, B.; Rensing, C.; Mahmood, S.; Liu, X.; Ma, L.Q. Interactive effects of As, Cd and $\mathrm{Zn}$ on their uptake and oxidative stress in As-hyperaccumulator Pteris vittata. Environ. Pollut. 2019, 248, 756-762. [CrossRef] [PubMed]

17. Ahmad, P.; Jaleel, C.A.; Salem, M.A.; Nabi, G.; Sharma, S. Roles of enzymatic and nonenzymatic antioxidants in plants during abiotic stress. Crit. Rev. Biotechnol. 2010, 30, 161-175. [CrossRef] [PubMed]

18. Abd_Allah, E.F.; Hashem, A.; Alam, P.; Ahmad, P. Silicon alleviates nickel-induced oxidative stress by regulating antioxidant defense and glyoxalase systems in mustard plants. J. Plant Growth Regul. 2019, 38, 1260-1273. [CrossRef]

19. Priyanka, N.; Geetha, N.; Manish, T.; Sahi, S.; Venkatachalam, P. Zinc oxide nanocatalyst mediates cadmium and lead toxicity tolerance mechanism by differential regulation of photosynthetic machinery and antioxidant enzymes level in cotton seedlings. Toxicol. Rep. 2021, 8, 295-302.

20. Kaya, C.; Ashraf, M.; Alyemeni, M.N.; Corpas, F.J.; Ahmad, P. Salicylic acid-induced nitric oxide enhances arsenic toxicity tolerance in maize plants by upregulating the ascorbate-glutathione cycle and glyoxalase system. J. Hazard. Mater. 2020, 399, 123020-123031. [CrossRef]

21. Foyer, C.H.; Noctor, G. Oxidant and antioxidant signalling in plants: A re-evaluation of the concept of oxidative stress in a physiological context. Plant Cell Environ. 2005, 28, 1056-1071. [CrossRef]

22. Ahmad, P.; Alam, P.; Balawi, T.H.; Altalayan, F.H.; Ahanger, M.A.; Ashraf, M. Sodium nitroprusside (SNP) improves tolerance to arsenic (As) toxicity in Vicia faba through the modifications of biochemical attributes, antioxidants, ascorbate-glutathione cycle and glyoxalase cycle. Chemosphere 2020, 244, 125480-125538. [CrossRef]

23. Abuelsoud, W.; Cortleven, A.; Schmülling, T. Photoperiod stress induces an oxidative burst-like response and is associated with increased apoplastic peroxidase and decreased catalase activities. J. Plant Physiol. 2020, 253, 153252-153268. [CrossRef] 
24. Sirhindi, G.; Mir, M.A.; Abd-Allah, E.F.; Ahmad, P.; Gucel, S. Jasmonic acid modulates the physio-biochemical attributes, antioxidant enzyme activity, and gene expression in Glycine max under nickel toxicity. Front. Plant Sci. 2016, 7, 591-602. [CrossRef] [PubMed]

25. Kozlowski, T.T.; Pallardy, S.G. Acclimation and adaptive responses of woody plants to environmental stresses. Bot. Rev. 2002, 68, 270-334. [CrossRef]

26. Arnon, D.I. Copper enzymes in isolated chloroplasts. Polyphenoloxidase in Beta vulgaris. Plant Physiol. 1949, 24, 1-15. [CrossRef] [PubMed]

27. Kosugi, H.; Kikugawa, K. Potential thiobarbituric acid-reactive substances in peroxidized lipids. Free Radic. Biol. Med. 1989, 7 , 205-208. [CrossRef]

28. Beauchamp, C.; Fridovich, I. Superoxide dismutase: Improved assays and an assay applicable to acrylamide gels. Ann. Biochem. 1971, 44, 276-287. [CrossRef]

29. Aebi, H. Catalase in vitro. Methods Enzymol. 1984, 105, 121-126. [PubMed]

30. Zhang, F.-Q.; Wang, Y.-S.; Lou, Z.-P.; Dong, J.-D. Effect of heavy metal stress on antioxidative enzymes and lipid peroxidation in leaves and roots of two mangrove plant seedlings (Kandelia candel and Bruguiera gymnorrhiza). Chemosphere 2007, 67, 44-50. [CrossRef]

31. Snedecor, G.W.; Cochran, W.G. Statistical Methods, 8th ed.; Iowa State University Press: Ames, IA, USA, 1989; Volume 54, pp. 71-82.

32. Sreekanth, T.; Nagajyothi, P.; Lee, K.; Prasad, T. Occurrence, physiological responses and toxicity of nickel in plants. Int. J. Environ. Sci. Technol. 2013, 10, 1129-1140. [CrossRef]

33. Seregin, I.; Kozhevnikova, A. Roles of root and shoot tissues in transport and accumulation of cadmium, lead, nickel, and strontium. Russ. J. Plant Physiol. 2008, 55, 1-22. [CrossRef]

34. Netty, S.; Wardiyati, T.; Maghfoer, M.; Handayanto, E. Bioaccumulation of nickel by five wild plant species on nickel-contaminated soil. IOSR J. Eng. 2013, 3, 1-6. [CrossRef]

35. Kumar, P.; Rouphael, Y.; Cardarelli, M.; Colla, G. Effect of nickel and grafting combination on yield, fruit quality, antioxidative enzyme activities, lipid peroxidation, and mineral composition of tomato. J. Plant Nutr. Soil Sci. 2015, 178, 848-860. [CrossRef]

36. Franks, S.J.; Weber, J.J.; Aitken, S.N. Evolutionary and plastic responses to climate change in terrestrial plant populations. Evol. Appl. 2014, 7, 123-139. [CrossRef] [PubMed]

37. Munzi, S.; Pirintsos, S.A.; Loppi, S. Chlorophyll degradation and inhibition of polyamine biosynthesis in the lichen Xanthoria parietina under nitrogen stress. Ecotoxicol. Environ. Saf. 2009, 72, 281-285. [CrossRef] [PubMed]

38. Siddiqui, M.H.; Alamri, S.; Khan, M.N.; Corpas, F.J.; Al-Amri, A.A.; Alsubaie, Q.D.; Ali, H.M.; Kalaji, H.M.; Ahmad, P. Melatonin and calcium function synergistically to promote the resilience through ROS metabolism under arsenic-induced stress. J. Hazard. Mater. 2020, 398, 122882-122955. [CrossRef]

39. Ahmed, N.; Habib, U.; Younis, U.; Irshad, I.; Danish, S.; Rahi, A.A.; Munir, T.M. Growth, chlorophyll content and productivity responses of maize to magnesium sulphate application in calcareous soil. Open Agric. 2020, 5, 792-800. [CrossRef]

40. Ahmad, P.; Tripathi, D.K.; Deshmukh, R.; Pratap Singh, V.; Corpas, F.J. Revisiting the role of ROS and RNS in plants under changing environment. Environ. Exp. Bot. 2019, 161, 1-3. [CrossRef]

41. Gajewska, E.; Bernat, P.; Długoński, J.; Skłodowska, M. Effect of nickel on membrane integrity, lipid peroxidation and fatty acid composition in wheat seedlings. J. Agron Crop Sci. 2012, 198, 286-294. [CrossRef]

42. Mir, M.A.; Sirhindi, G.; Alyemeni, M.N.; Alam, P.; Ahmad, P. Jasmonic acid improves growth performance of soybean under nickel toxicity by regulating nickel uptake, redox balance, and oxidative stress metabolism. J. Plant Growth Regul. 2018, 37, 1195-1209. [CrossRef]

43. Alsahli, A.A.; Bhat, J.A.; Alyemeni, M.N.; Ashraf, M.; Ahmad, P. Hydrogen Sulfide $\left(\mathrm{H}_{2} \mathrm{~S}\right)$ Mitigates Arsenic (As)-Induced Toxicity in Pea (Pisum sativum L.) Plants by Regulating Osmoregulation, Antioxidant Defense System, Ascorbate Glutathione Cycle and Glyoxalase System. J. Plant Growth Regul. 2021, 40 (Suppl. S1), 2515-2531. [CrossRef]

44. Sachan, P.; Lal, N. An Overview of Nickel $\left(\mathrm{Ni}^{2+}\right)$ Essentiality, Toxicity and Tolerance Strategies in Plants. Asian J. Biol. 2017, 2, 1-15. [CrossRef]

45. Anjum, S.A.; Tanveer, M.; Hussain, S.; Bao, M.; Wang, L.; Khan, I.; Ullah, E.; Tung, S.A.; Samad, R.A.; Shahzad, B. Cadmium toxicity in Maize (Zea mays L.): Consequences on antioxidative systems, reactive oxygen species and cadmium accumulation Environ. Sci. Pollut. Res. 2015, 22, 17022-17030. [CrossRef] [PubMed]

46. Zeng, C.-Q.; Liu, W.-X.; Hao, J.-Y.; Fan, D.-N.; Chen, L.-M.; Xu, H.-N.; Li, K.-Z. Measuring the expression and activity of the CAT enzyme to determine Al resistance in soybean. Plant Physiol. Biochem. 2019, 144, 254-263. [CrossRef] [PubMed]

47. Nanda, R.; Agrawal, V. Elucidation of zinc and copper induced oxidative stress, DNA damage and activation of defence system during seed germination in Cassia angustifolia Vahl. Environ. Exp. Bot. 2016, 125, 31-41. [CrossRef]

48. Nadarajah, K.K. ROS homeostasis in abiotic stress tolerance in plants. Int. J. Mol. Sci. 2020, 21, 5208. [CrossRef]

49. Maathuis, F.J. Physiological functions of mineral macronutrients. Curr. Opin. Plant Biol. 2009, 12, 250-258. [CrossRef]

50. Tanveer, M. An Overview of Nickel Toxicity in Plants. In Metal Toxicology Handbook; CRC Press: Boca Raton, FL, USA, 2021; pp. $465-474$.

51. Ishtiaq, S.; Mahmood, S.; Athar, M. Alteration of macronutrients, metal translocation and bioaccumulation as potential indicators of nickel tolerance in three Vigna species. Adv. Environ. Res. 2014, 3, 71-86. [CrossRef] 
52. Callahan, D.L.; Baker, A.J.; Kolev, S.D.; Wedd, A.G. Metal ion ligands in hyperaccumulating plants. JBIC J. Biol. Inorg. Chem. 2006, 11, 2-12. [CrossRef]

53. Hasanzadeh, M.; Hazrati, N. Calcium sensing and signaling in plants during metal/metalloid stress. In Metal and Nutrient Transporters in Abiotic Stress; Elsevier: Amsterdam, The Netherlands, 2021; pp. 169-197.

54. Berni, R.; Luyckx, M.; Xu, X.; Legay, S.; Sergeant, K.; Hausman, J.-F.; Lutts, S.; Cai, G.; Guerriero, G. Reactive oxygen species and heavy metal stress in plants: Impact on the cell wall and secondary metabolism. Environ. Exp. Bot. 2019, 161, 98-106. [CrossRef]

55. Bloom, A.J. Metal regulation of metabolism. Curr. Opin. Chem. Biol. 2019, 49, 33-38. [CrossRef]

56. Estravis-Barcala, M.; Mattera, M.G.; Soliani, C.; Bellora, N.; Opgenoorth, L.; Heer, K.; Arana, M.V. Molecular bases of responses to abiotic stress in tress. J. Exp. Biol. 2020, 71, 3765-3779.

57. Bücker-Neto, L.; Paiva, A.L.S.; Machado, R.D.; Arenhart, R.A.; Margis-Pinheiro, M. Interactions between plant hormones and heavy metals responses. Gen. Mol. Res. 2017, 40, 373-386. 